\title{
Meningkatkan Aktivitas dan Hasil Belajar Penanganan Barang Bawaan Tamu Melalui Model Cooperatif Learning dengan Teknik Bermain Peran (Role Play)
}

\author{
Ni Nyoman Wirati*
}

SMKN 1 Mas Ubud, Gianyar, Indonesia

A R T I C L E I N F O

Article history:

Received 19 August 2020

Received in revised form

30 September 2020

Accepted 10 October 2020

Available online 29

November 2020

Kata Kunci:

Cooperative Learning,

bermain peran (role play),

aktivitas dan hasil belajar

Keywords:

Cooperative Learning, role

play, activities and

learning outcomes dengan teknik bermain peran (role play) menuntun siswa untuk bekerja sama dalam kelompok dalam melakukan peran sehingga menemukan konsep baru. Dengan demikian melalui penerapan model pembelajaran cooperatif learning dengan teknik bermain peran (role play) dalam pembelajaran merupakan strategi alternatif yang efektif untuk meningkatkan aktivitas dan hasil belajar siswa.

A B S T R A C T

This research aimed to determine the advantages of the Cooperative Learning Model with role play techniques in learning handling guest luggage in Front Office Department of the fifth semester of the 2019/2020 Academic Year students of XII AP 3 SMK N Mas Ubud, the number of the students involved in this study are 36 persons. This step is necessary given the relatively low activity and learning outcomes. The objects in this study are the activities and student learning outcomes. This action research design was carried out in two cycles. Student learning activity data were recorded using observation sheets and learning outcome data were obtained using tests at the end of each cycle. From the observation data in the first and second cycles, it was found that student learning activities had increased by $8.00 \%$. The learning outcome data from the first cycle to the second cycle also increased by $8.11 \%$. This increase in activity and learning outcomes can occur considering the application of the cooperative learning model with role playing techniques which leads students to work together in groups in performing roles so as to find new concepts. Thus, through the application of the cooperative learning model with role play techniques in learning is an effective alternative strategy to increase the activities and learning outcomes of class XII students at SMK Negeri 1 Ubud for the academic year of 2019/2020.

\section{Pendahuluan}

Indonesia pada masa sekarang ini dihadapkan dengan berbagai macam permasalahan baik yang berasal dari luar maupun dari dalam negara itu sendiri. Permasalahan tersebut terjadi sebagai akibat dari 
banyaknya perubahan perubahan yang mendunia, contohnya adalah kemajuan IPTEK, pergeseran nilai sosial dan kebudayaan pada masyarakat. Pendidikan sebagai lembaga yang dinamis juga merasakan pengaruh atas perubahan tersebut. Perubahan budaya yang membawa dampak terhadap kemajuan dan perkembangan pendidikan. Pendidikan dibutuhkan manusia untuk berkembang. Manusia yang berkualitas dan mampu bersaing dapat diciptakan melalui pendidikan yang baik. Kualitas pembelajaran yang masih jauh dari di bawah kata sempurna menjadikan usaha pembangunan sumber daya manusia berjalan dengan lambat (Charron et al., 2013). Kualitas pendidikan di Indonesia diharapkan mampu menjawab tuntutan perkembangan zaman (Adha, 2019).

Dalam rangka meningkatkan mutu pendidikan di Indonesia diperlukan upaya yang serius untuk meningkatkan kualitas guru. Seorang guru memiliki peran yang paling besar dalam upaya inovasi serta peningkatan mutu pendidikan melalui inovasi dalam proses pembelajaran. Peningkatan mutu pendidikan dapat dimulai dengan meningkatkan mutu guru dalam mengajar dan berprilaku profesional. Berbagai penataran dan pelatihan guru menjadi salah satu bentuk dari upaya tersebut walaupun kurang membekas dalam keseharian aktivitas guru. Hal inilah yang mendasari perlunya perbaikan yang menitik beratkan kepada kondisi nyata di lapangan, mulai dari kondisi di kelas, sekolah, dan guru. Pelaksanaan sertifikasi guru sebagai amanat dari Undang-Undang (UU) Nomor 14 Tahun 2005 tentang Guru dan Dosen diharapkan berperan dalam peningkatan kualitas pendidikan (Monawati, 2016). Dengan adanya Pendidikan bermutu maka akan diahasilkan sebuah sumber daya manusia yang bermutu pula.

Pendidikan merupakan kegiatan yang kompleks, dan meliputi berbagai komponen yang berkaitan erat satu sama lain. Oleh sebab itu, apabila pendidikan ingin dilaksanakan secara terencana dan teratur, maka berbagai faktor yang terlibat dalam pendidikan harus dipahami terlebih dahulu. Berbagai komponen dalam sistem pendidikan, baik secara mikro maupun dalam kajian makro perlu dikenali secara mendalam sehingga komponen-komponen tersebut dapat difungsikan dan dikembangkan guna mengoptimalkan garapan pendidikan tersebut ke arah pencapaian tujuan pendidikan yang ditetapkan (Wahyudi et al., 2006) Pendidikan nilai merupakan salah satu komponan dalam pendidikan kewarganegaraan yang tidak hanya mendidik para peserta didiknya untuk menjadi manusia yang cerdas, tetapi juga membangun kepribadiannya agar memiliki akhlak mulai. Saat ini pendidikan nilai di Indonesia dinilai tidak masalah dengan peran pendidikan dalam mecerdaskan para peserta didiknya, namun dinilai kurang berhasil dalam membangun kepribadian peserta didik agar berakhlak mulia. Oleh karena itu peran pendidikan nilai dipandang sebagai kebutuhan yang sangat mendesak. Pendidikan nilai sudah tentu penting untuk semua tingkat pendidikan, yakni dari sekolah dasar hingga perguruan tinggi. Secara umum, pendidikan nilai sesungguhnya dibutuhkan semenjak anak masih dini. Apabila kepribadian seseorang sudah terbentuk sejak usia dini, ketika dewasa tidak akan mudah berubah meski godaan atau rayuan datang begitu menggiurkan. Dengan adanya pendidikan nilai semenjak usia dini, diharapkan persoalan mendasar dalam dunia pendidikan yang akhir-akhir ini sering menjadi keprihatinan bersama dapat diatasi. Pendidikan nilai dan pendidikan kewarganegaraan di Indonesia sangat diharapkan dapat mencetak alumni pendidikan yang unggul, yakni para anak bangsa yang beriman, bertakwa, berakhlak mulia, mempunyai keahlian dibidangnya, dan berkarakter warga negara yang baik (Azzat, 2011; Sutrisno, 2016).

Guru memberikan peranan penting didalam pendidikan terutama didalam kegiatan belajar mengajar, agar kegiatan belajar mengajar berhasil maka guru dituntut untuk menguasai dan memahami berbagai keterampilan yang dapat mendukung efektivitas dan efesiensi kegiatan belajar mengajar. Guru adalah salah satu komponen pendidikan yang sangat berperan dalam usaha pembentukan sumber daya manusia yang potensial di bidang pembangunan. Oleh karena itu, guru merupakan salah satu unsur kependidikan harus berperan serta secara aktif dalam menempatkan kedudukannya sebagai tenaga profesional. Pada diri guru terletak tanggung jawab untuk membawa siswa pada suatu kedewasaan atau taraf kematangan tertentu. (Sardiman, 2012) mengatakan bahwa guru tidak sematamata sebagai "pengajar" yang melakukan transfer of knowledge, tetapi juga sebagai "pendidik" yang melakukan transfer of values dan "pembimbing" yang memberikan pengarahan dan menuntun siswa dalam belajar" (Firmansyah, 2015). Proses intersai yang baik antara siswa dan suber belajara dalam hal ini guru dan sarana yang lainnya dapat memepengaruhi hasil belajar.

Menurut (Suprijono, 2012), hasil belajar adalah polapola perbuatan, nilai-nilai, pengertianpengertian, sikapsikap, apresiasi dan keterampilan. Selanjutnya (Supratiknya, 2012) mengemukakan bahwa hasil belajar yang menjadi objek penilaian kelas berupa kemampuan-kemampuan baru yang diperoleh siswa setelah mereka mengikuti proses belajar-mengajar tentang mata pelajaran tertentu. Dalam sistem pendidikan nasional rumusan tujuan pendidikan mengacu pada klasifikasi hasil belajar dari Bloom yang secara garis besar yaitu aspek kognitif, aspek afektif dan aspek psikomotor (Widodo, 2013). Menurut Sukmadinata dalam (Sukriswati, 2016) menyatakan bahwa hasil belajar merupakan realisasi atau pemekaran dari kecakapan-kecakapan potensi atau kapasitas yang dimiliki seseorang. Menurut Nana 
Sudjana dalam (Sukriswati, 2016) hasil belajar merupakan kemampuan- kemampuan yang dimiliki setelah ia menempuh pengalaman belajarnya (proses belajar mengajar) (Ariyanto, 2016).

Salah satu indikator keberhasilan pembelajaran Front office disekolah dapat dilihat pada kemampuan siswa untuk melayani tamu pada saat tamu melakukan cek in atau sedang menginap di hotel, karena Front Office atau Kantor Depan bagi hotel dikenal sebagai The first and the last impression of the guest. Dengan demikian penangan tamu mulai dari cek in, selama tinggal dan cek out harus dilayani dengan baik sesuai dengan standar operasional prosedur, pelayanan yang diberikan secara baik akan membuat tamu merasa puas sehingga menimbulkan kesan positif. Kurikulum Front Office tahun 2013 untuk SMK dengan jelas menyatakan bahwa belajar Front Office pada dasarnya belajar menguasai kompetensi pelayanan terhadap tamu. Kenyataan yang terjadi di SMK N 1 Mas Ubud hasil belajar Front office sampai saat ini relatif rendah. Secara umum siswan cenderung tidak menyukai Front Office. Para siswa yang kemampuan intelektualnya tergolong menengah kebawah serig menghadapi kesulitan dalam penanganan barang bawaan tamu. Penyebab utama dari keadaan diatas adalah model pembelajaran yang diterapkan dikelas secara umum menekankan pada teori, akibat yang ditimbulkan adalah aktivitas siswa dalam pembelajaran cenderung rendah dan kurang bergairah. Hal ini dikuatkan oleh Piaget yang menyatakan bahwa siswa yang rata - rata umur 16 tahun masih berada dalam masa transisi antara tahap operasional konkrit dan operasional formal. Sehingga dalam pembelajaran membutuhkan kehadiran benda - benda konkrit atau melakukan aktivitas visual dari konsep - konsep yang abstrak. (Budiningsih, 2005:38-40).

Perbaikan pembelajaran dipandang sangat penting, untuk dilaksanakan dengan memberdayakan potensi siswa melalui strategi pembelajaran yang berasosiasi dengan Contextual Teaching Learning (CTL), yaitu pendekatan ketrampikan proses dengan model Cooperatif learning dengan teknik bermain peran (Role Play). Seharusnya guru selalu inovatif dan kreatif merancang dan mengimplementasikan teknik pembelajaran penanganan tamu dengan teknik bermain peran pada siswa. Mengupayakan agar proses pembelajaran lebih menarik dan menciptakan situasi belajar yang nyaman dan menyenangkan. Dengan demikian siswa menjadi senang belajar. Enam tahap pembelajaran cooperatif itu dirangkum pada sintaks model pembelajaran cooperatif pada tabel berikut.

Tabel 1. Sintak model cooperatiflearning

\begin{tabular}{|c|c|}
\hline Fase-fase & Tingkah laku guru \\
\hline $\begin{array}{l}\text { FASE } 1 \text { Menyampaikan tujuan dan memotivasi } \\
\text { siswa }\end{array}$ & $\begin{array}{l}\text { Guru menyampaikan tujuan pelajaran yang ingin } \\
\text { dicapai pada pelajaran tersebut dan memotivasi } \\
\text { siswa belajar }\end{array}$ \\
\hline FASE 2 Menyajikan informasi & $\begin{array}{l}\text { Guru menyajikan kepada siswa dengan jalan } \\
\text { demonstrasi atau lewat bahan bacaan }\end{array}$ \\
\hline $\begin{array}{l}\text { FASE } 3 \text { Mengorganisasikan siswa kedalam } \\
\text { kelompok kelompok belajar }\end{array}$ & $\begin{array}{l}\text { Guru menjelaskan kepada siswa bagaimana } \\
\text { caranya membentuk kelompok belajar dan } \\
\text { membantu setiap kelompok agar melakukan } \\
\text { transisi secara efesien }\end{array}$ \\
\hline $\begin{array}{l}\text { FASE } 4 \text { Membimbing kelompok bekerja dan } \\
\text { belajar }\end{array}$ & $\begin{array}{l}\text { Guru membimbing kelompokkelompok belajar } \\
\text { pada saat mereka mengerjakan tugas mereka } \\
\text { Guru mengevaluasi hasil belajar tentang materi }\end{array}$ \\
\hline FASE 5 Evaluasi & $\begin{array}{l}\text { yang telah dipelajari atau masing-masing } \\
\text { kelompok mempersentasikan hasil kerjanya }\end{array}$ \\
\hline FASE 6 Memberikan penghargaan & $\begin{array}{l}\text { Guru mencari cara-cara untuk menghargai baik } \\
\text { upaya maupun hasil belajar individu dan } \\
\text { kelompok }\end{array}$ \\
\hline
\end{tabular}

Sumber: Agus Suprijono (2009: 65).

Berdasarkan langkah di atas, langkah dari penerapan metode Role Playing adalah mulai dari: Memanaskan suasana kelas, pembentukan kelompok, mengatur setting tempat latihan, membagi skenario, bermain di depan kelas tiap kelompok, berdiskusi dan evaluasi, peran kelompok selanjutnya, diskusi dan evaluasi kembali serta penarikan kesimpulan dan berbagi pengalaman. (Nurhasanah et al., 2016) Role playing merupakan suatu metode pembelajaran yang mengajak siswa untuk terlibat langsung dalam pembelajaran, penguasaan bahan pelajaran berdasarkan pada kreatifitas serta ekspresi siswa dalam meluapkan imajinasinya terkait dengan bahan pelajaran yang ia dalami tanpa adanya keterbatasan kata dan gerak, namun tidak keluar dari bahan ajar. Yamin (Ananda, 2018) menjelaskan metode role-playing adalah metode yang melibatkan interaksi antara dua siswa atau lebih tentang suatu topik atau situasi. 
Metode Role Playing atau metode bermain peran adalah metode yang bertujuan untuk membantu siswa menemukan diri (jati diri) di dunia sosial dan diarahkan pada upaya pemecahan masalah-masalah yang berkaitan dengan hubungan antar manusia (Dwi Oktavia \& Kusumawati, 2019; Murtadlo, 2012). Dengan metode role-playing dituntut kemampuan siswa untuk dapat memerankan suatu situasi yang mungkin pernah dialami dalam kesehariannya. Dengan menggunakan metode role-playing siswa juga akan merasakan proses pembelajaran yang berbeda dari yang biasa dilakukannya selama ini (Ananda, 2018).

Penelitian yang dilakukan oleh (Kristin, 2018) menyatakan bahwa hasil analisis model pembelajaran role playing mampu meningkatkan hasil belajar siswa mulai dari yang terendah 1,65\% sampai yang tertinggi $64,32 \%$ dengan rata-rata $23,32 \%$. Kemudian penelitian yang dilakukan oleh (Inten, 2017) menyatakan bahwa setelah pembelajaran disampaikan melalui metode bermain peran, baik pada tema rumah, pasar ataupun rumah sakit terlihat adanya peningkatan kemampuan komunikasi anak. Selain itu, penelitian yang dilakukan oleh (Wahyuni et al., 2017) menyatakan faktor yang mempengaruhi aktivitas belajar siswa tinggi adalah model pembelajaran Role Playing yang menekankan kepada kemampuan bekerja sama, komunikatif dan menginter pretasikan suatu kejadian. (Utami et al., 2018) menyatkan penggunaan model pembelajaran role playing yang berbantuan mediakomik, mengalami peningkatan dari 31 peserta didik terdapat 31 peserta didik yang memperoleh nilai lebih dari 65 dengan rata-rata 78 dan presentasi data ketuntasan 100\%. Sejalan dengan hal tersebut, (Dewi, 2017) hasil belajar yang mengalami perubahan kearah yang positif dari 25,81\% atau 8 mahasiswa menjadi $64,52 \%$ atau 20 mahasiswa, dengan kata lain hasil belajar dari proses pembelajaran menggunakan model Role Playing mengalami peningkatan.

Berdasarkan pemaparan diatas, maka perlu adanya penerapan suatu model pembelajaran yang dapat merangkum semua teori yang sudah di jelaskan. Maka penelitian ini bertujuan untuk mengetahui aktivitas dan hasil belajar penanganan barang bawaan tamu melalui model cooperatif learning dengan teknik bermainp (role play).

\section{Metode}

Penelitian ini dilakukan pada semester ganjil tahun pelajaran 2019/2020, yaitu mulai minggu pertama bulan agustus 2019 dan berakhir pada minggu pertama pada bulan November 2019. Waktu penelitian ini dipilih karena bertepatan dengan pembahasan materi" Penanganan Barang Bawaan Tamu" Penelitian tindakan kelas ini dilakukan di kelas XII AP 3 SMK N 1 Mas Ubud. Pemilihan kelas ini didasarkan pada asumsi bahwa kelas XII AP 3 semester ganjil tahun pelajaran 2019/2020 terdiri dari siswa-siswa dengan tingkat pengetahuan yang beraneka ragam, yaitu dengan kategori rendah, sedang, dan tinggi.

Subjek dalam penelitian ini adalah siswa kelas XII AP 3 Tahun Pelajaran 2019/2020. Siswa kelas XII AP 3 terdiri dari 37 orang siswa dengan 18 orang laki-laki dan 19 orang perempuan. Objek dalam penelitian ini adalah meningkatkan aktivitas dan hasil belajar front office dengan menerapkan model cooperatif learning dengan teknik bermain peran (role play) dalam materi "Penanganan barang bawaan tamu". Sumber data yang digunakan dalam penelitian tindakan ini adalah sumber data primer yaitu data yang langsung dan segera diperoleh dari subjek penelitian. Sumber data yang dimaksud adalah aktivitas belajar siswa dan hasil belajar siswa pada materi "Penanganan barang bawaan tamu", dari siswa kelas XII AP 3 Tahun Pelajaran 2019/2020. Data aktivitas belajar siswa diperoleh melalui observasi sedangkan data hasil belajar siswa diperoleh dari penyebaran tes.

\section{Hasil dan Pembahasan}

Penelitian Deskripsi kondisi awal tentang subjek yang diteliti telah diuraikan pada bagian subjek dan objek penelitian. Data tentang aktivitas siswa sebelum diberi tindakan Role Play tergambar dari aktivitas siswa saat mengikuti materi sebelumnya yang berpengaruh atau berimplikasi pada hasil belajar pada materi tersebut. Sedangkan hasil belajar yang diperoleh siswa sebelum diberikan tindakan dengan metode belajar Role Play tergambar dari perolehan nilai yang diperoleh masing masing siswa pada saat mengikuti tes awal. Tes awal yang dilaksanakan pada hari Senin, 5 Agustus 2019 masing-masing selama satu jam pelajaran mendapatkan data sebagai berikut. Dari 37 orang siswa kelas XII AP 3 yang mengikuti tes awal dengan batas kkm 80, hanya 8 orang yang memperoleh nilai di atas kkm, sisanya lagi 29 orang memperoleh nilai dibawah $\mathrm{kkm}$. Jadi siswa yang memperoleh nilai lebih besar atau sama dengan kkm baru mencapai $21,62 \%$ dan sisanya lagi 78,38 \% nilai siswa berada di bawah kkm.

Berdasarkan data baik dari siklus pertama maupun siklus kedua, diperoleh gambaran bahwa penerapan model cooperatif learning dengan teknik role paly dalam materi Penanganan barang bawaan tamu dapat meningkatkan aktivitas siswa dalam proses pembelajaran. Pada siklus pertama tingkat 
aktivitas siswa mencapai 79.11\% tergolong dalam katagori aktif dan pada siklus kedua mencapai $87.11 \%$ tergolong dalam katagori sangat aktif. Dari kedua siklus tersebut terjadi peningkatan aktivitas siswa sebesar 8\%. Dari data yang disajikan juga dapat diketahui gambaran hasil belajar siswa pada siklus pertama yang dicapai siswa $86,49 \%$ dan pada siklus kedua diperoleh gambaran hasil belajar siswa mencapai 94,59\% dan terjadi peningkatan hasil belajar sebesar 8,11\%.

Penerapan model cooperatif learning dengan teknik Role Play dalam materi Penanganan barang bawaan tamu dalam proses pembelajaran dapat memotivasi siswa untuk aktif dalam setiap tahapan yang harus dilakukan sesuai langkah model tersebut. Hal ini didukung oleh pedoman penilaian yang memberikan skor pada masing-masing tahapan kegiatan. Jika siswa tidak mengikuti salah satu tahap kegiatan maka siswa tidak akan memperoleh skor pada tahapan tersebut. Apalagi jika tahapan yang tidak dilakukan pada tahapan awal, akan berimplikasi atau berpengaruh pada tahapan berikutnya. Pada siklus pertama aktivitas siswa baru mencapai $79.11 \%$ hal ini disebabkan karena dalam proses pembelajaran, siswa baru diperkenalkan model cooperatif learning dengan teknik bermain peran jadi tidak semua tahapan kegiatan dapat dilakukan sehingga skor mereka terbuang. Aktivitas siswa pada siklus kedua meningkat sebesar 8\% dari siklus pertama. Peningkatan aktivitas ini disebabkan oleh karena rekomendasi-rekomendasi yang diberikan kepada siswa dalam melaksanakan setiap tahapan model cooperatif learning dengan teknik Role Play dilaksanakan dengan benar oleh siswa. Pada siklus kedua sebagian besar siswa sudah mampu memerankan perannya, menguasai dialog, dan mendiskusikan hasil pengamatan terhadap kelompok lain, serta menerapkan konsep-konsep baru yang di dapat untuk menyelesaikan persoalan. Jadi secara umum penerapan model cooperatif learning dengan teknik bermain peran dalam proses pembelajaran dapat meningkatkan aktivitas belajar siswa dalam materi Penanganan barang bawaan tamu.

Penerapan model cooperatif learning dengan teknik bermain peran dalam proses pembelajaran juga berpengaruh terhadap hasil belajar yang diperoleh siswa. Dari kedua siklus yang dilakukan diperoleh gambaran bahwa terjadi peningkatan hasil belajar sebesar 8,11\%. Penigkatan hasil belajar ini disebabkan oleh kemampuan siswa dalam menerapkan konsep-konsep baru yang diperoleh untuk menyelesaikan persoalan meningkat. Penelitian ini didikung dari pernyataan (Iskandar, 2017) pembelajaran Pendidikan Pancasila dan Kewarganegaraan menggunakan metode pembelajaran bermain peran dapat meningkatkan keaktifan dan keterlibatan siswa dalam mengikuti kegiatan pembelajaran, sehingga hasil belajar siswa mengalami peningkatan. Selain itu, (Husada et al., 2019) menyatakan peningkatan kemampuan berbicara menggunakan metode bermainperan yang sangat baik jika dibandingkan dengan kemampuan berbicara pada Pratindakan Peningkatan hasil belajar ini juga disebabkan oleh jenis soal yang dipakai menguji kemampuan siswa sangat berkaitan dengan kejadian-kejadian sehari-hari. Dengan kebiasaan siswa bekerja secara sistematis sampai menarik kesimpulan. Peningkatan belajar ini juga disebabkan disebabkan oleh rekomendasi-rekomendasi yang diberikan pada siklus pertama dapat doadopsi dengan baik oleh siswa. Peningkatan hasil belajar ini juga disebabkan oleh karakteristik materi yang memiliki tingkat kesulitan yang setara.

Perbandingan kompleksitas materi pada siklus I dengan siklus II hampir sama, demikian juga dengan sarana pendukung yang ada untuk mendukung pelaksanaan pembelajaran pada siklus pertama dan kedua hampir sama. Jadi secara substansial karena kondisi materi yang hampir sama pada siklus pertama dan siklus kedua, tetapi dengan peningkatan perlakuan pada kegiatan pembelajaran sudah wajar akan berimplikasi pada peningkatan hasil belajar. Penerapan model cooperatif learning dengan teknik Role Play dalam proses pembelajaran dalam materi penanganan barang bawaan tamu sejalan dengan Teori Konstruktifisme.

Dimana setiap siswa aktif secara mental untuk memilih atau mengamati beberapa masukan sensori baru dalam lingkungannya, baik berasal dari buku-buku teks maupun dari pengalaman belajar lainnya yang disajikan guru dalam hal ini siklus pertama. Masukan-masukan yang diperhatikan dan dipilih siswa kemudian dimaknai dengan menyusun hubungan-hubungan antara masukan sensori baru dengan pengetahuan relevan yang telah dimiliki. Jadi dengan menerapakan Model cooperatif learning dengan teknik Role Play siswa bisa mengkaitkan efisiensi dan efektivitas belajar, dapat belajar mandiri, dapat memecahkan masalah dengan sistematis, dan dapat menganalisis masalah menjadi masalah-masalah yang lebih rinci, dan siswa juga dapat mengkonstruksi makna dari hubungan-hubungan antara sensori dan pengetahuan yang telah ada. Hal ini didukung oleh penelitian yang dilakukan (Fauzi, 2017) hasil belajar siswa pada mata pelajaranPKn materi keputusan bersama menggunakan model mind mapping yang di variasi dengan role playing telah mencapai KKM dengan persentase $91,87 \%$. Terdapat pula penelitian yang dilakukan (Nurhasanah et al., 2016) metode role playing dapat meningkatkan hasil belajar siswa pada materi hubungan mahluk hidup dengan lingkungannya, tetapi secara umum dapat dikatakan bahwa pembelajaran hubungan mahluk hidup dengan lingkungannya di SDN Sindang II dengan menggunakan 
metode roleplaying berhasil, baik dalam perencanaan pembelajaran, proses pembelajaran, maupun dari perolehan nilai siswa pada akhir pembelajaran.

\section{Simpulan Dan Saran}

Penelitian Berdasarkan pada penjelasan yang diuraikan dalam pembahasan di atas dapat disimpulkan beberapa hal sebagai berikut: 1) Melalui penerapan model pembelajaran cooperatif learning dengan teknik bermain peran (Role Play) dapat meningkatkan aktivitas siswa kelas XII AP 3 semester ganjil SMK Negeri 1 Mas Ubud Tahun Pelajaran 2019/2020. 2) Melalui penerapan model cooperatif learning dengan teknik bermain peran (Role Play) dalam proses pembelajaran dapat meningkatkan hasil belajar siswa kelas XII AP 3 semester ganjil SMK Negeri 1 Mas Ubud Tahun Pelajaran 2019/2020

Berdasarkan simpulan di atas, dapat direkomendasikan beberapa saran seperti berikut: 1) Bagi rekan-rekan guru front office dapat mempertimbangkan penerapan model pembelajaran cooperatif learning dengan teknik Role Play sebagai salah satu alternatif, guna meningkatkan aktivitas dan hasil belajar siswa pada materi penanganan barang bawaan tamu. 2) Bagi siswa yang sedang mengikuti pembelajaran di kelas XII khususnya pada materi penanganan barang bawaan tamu, hendaknya siswa lebih percaya diri dalam memerankan peran yang diberikan, menguasai dialog dan menerapkan hasil kesimpulan untuk memecahkan persoalan. Dan 3) Bagi sekolah hendaknya memberikan motivasi kepada guru-guru untuk selalu melakukan inovasi dalam pembelajaran sehingga dapat ditemukan metode atau model yang tepat untuk mengajarkan suatu materi.

\section{Daftar Rujukan}

Adha, Maulana Amirul. 2019. Analisis Komparasi Sistem Pendidikan Indonesia dan Finlandia . Jurnal Studi Manajemen Pendidikan vol. 3, no. 2, November 2019. http://dx.doi.org/10.29240/jsmp.v3i2.1102

Ananda, R. (2018). Peningkatan Pembelajaran PKn dengan Penerapan Metode Role-Playing Siswa Kelas II $\begin{array}{lllll}\text { SDN } & 003 & \text { Bangkinang } & \text { Kota. Jurnal }\end{array}$ https://media.neliti.com/media/publications/278080-peningkatan-pembelajaran-pkn-denganpene-2358075c.pdf

Ariyanto, Metta. 2016. Peningkatan Hasil Belajar Ipa Materi Kenampakan Rupa Bumi Menggunakan Model Scramble . Jurnal Profesi Pendidikan Dasar, Vol. 3, No. 2, Desember 2016. https://doi.org/10.23917/ppd.v3i2.3844

Dewi, T. A. (2017). Efektivitas Model Role Playing Dalam Meningkatkan Kompetensi Mahasiswa Pada Mata Kuliah Manajemen Keuangan. PROMOSI: Jurnal Program Studi Pendidikan Ekonomi,5(1). http://dx.doi.org/10.24127/ja.v5i1.850

Djihadah, Nuryati . 2020. Kecerdasan Emosional dan Kepemimpinan Kepala Madrasah dalam Aplikasi Penguatan Pendidikan Karakter (PPK) di Madrasah . Jurnal Pendidikan Madrasah, Volume 5, Nomor 1, Mei 2020. https://doi.org/10.14421/jpm.2020.51-01

Fauzi, A. Z. A. (2017). Meningkatkan Hasil Belajar Siswa Pada Mata Pelajaran Pkn Materi Keputusan Bersama Melalui Model Mind Mapping Yang Divariasi Dengan Role Playing Di Kelas V SDN Teluk Tiram 2 Banjarmasin. Paradigma, 9(2). https://ppjp.ulm.ac.id/journal/index.php/paradigma/article/view/2802

Firmansyah, Dani. 2015. Pengaruh Strategi Pembelajaran Dan Minat Belajar Terhadap Hasil Belajar Matematika . Jurnal Pendidikan Unsika Volume 3 Nomor 1, Maret 2015. https://journal.unsika.ac.id/index.php/judika/article/view/199

Husada, A., Untari, M. F. A., \& Tsalatsa, A. N. (2019). Peningkatan Keterampilan Berbicara dengan Metode Bermain Peran Pada Siswa. Journal of Education Action Research,3(2), 124-130. http://dx.doi.org/10.23887/jear.v3i2.17268

Iskandar, R. (2017). Menigkatkan Hasil Belajar Pendidikan Pancasila dan Kewarganegaraan Melalui Metode Role Playing di Kelas IV Sekolah Dasar. Jurnal Ilmiah Pendidikan Guru Sekolah Dasar, 1(02). https://doi.org/10.31326/jipgsd.v1i02.102

Monawati. 2016. Upaya Meningkatkan Hasil Belajar Siswa Melalui Lesson Study Pada Penjumlahan Pecahan Di Kelas Iv Sdn Lamsayeun . Jurnal Pesona Dasar Vol. 3 No.4, Oktober 2016. http://www.jurnal.unsyiah.ac.id/PEAR/article/view/7537 
Nurhasanah, I. A., Sujana, A., \& Sudin, A. (2016). Penerapan Metode Role Playing untuk Meningkatkan Hasil Belajar Siswa pada Materi Hubungan Mahluk Hidup dengan Lingkungannya. Jurnal Pena Ilmiah, 1(1), 611-620. https://doi.org/10.23819/pi.v1i1.2992

Nurkholis. 2013. Pendidikan Dalam Upaya Memajukan Teknologi . Jurnal Kependidikan, Vol. 1 No. 1 Nopember 2013. https://doi.org/10.24090/jk.v1i1.530

Sholichah, Aas Siti . 2018. Teori-Teori Pendidikan Dalam Al-Qur'an . Jurnal Edukasi Islami Jurnal Pendidikan Islam Vol. 07/No.1, April 2018. http://dx.doi.org/10.30868/ei.v7i01.209

Sutrisno. 2016. Berbagai Pendekatan Dalam Pendidikan Nilai Dan Pendidikan Kewarganegaraan . Jurnal Dimensi Pendidikan dan Pembelajaran Vol.5 Januari 2016. DOI : 10.24269/dpp.v4i1.56

Utami, A. D., \& Setyawan, D. (2018). Penerapan Model Role Playing Berbantuan Media Komik untuk Meningkatkan Hasil Belajar Bahasa Indonesia pada Peserta Didik Kelas V SDN-1 Telangkah Tahun Pelajaran 2016/2017. Tunas: Jurnal Pendidikan Guru Sekolah Dasar, 4(1), 18-23. https://doi.org/10.33084/tunas.v4i1.496

Wahyuni, R., Utami, C., \& Husna, N. (2016). Pengaruh Model Role Playing Terhadap Kemampuan Komunikasi Matematis Siswa pada Materi Fungsi Komposisi Kelas XI SMA Negeri 6 Singkawang.Jurnal Pendidikan Matematika Indonesia, 1(2), 81-86. http://dx.doi.org/10.26737/jpmi.v1i2.87

Widodo, Heri. 2015. Potret Pendidikan Di Indonesia Dan Kesiapannya Dalam Menghadapi Masyarakat Ekonomi Asia (Mea) . Jurnal Cendekia Vol. 13 No. 2, Juli - Desember 2015. https://doi.org/10.21154/cendekia.v13i2.250

Widodo. 2013. Peningkatan Aktivitas Belajar Dan Hasil Belajar Siswa Dengan Metode Problem Based Learning Pada Siswa Kelas Viia Mts Negeri Donomulyo Kulon Progo Tahun Pelajaran 2012/2013. Jurnal Fisika Indonesia No: 49, Vol Xvii, Edisi April 2013. https://doi.org/10.22146/jfi.24410 